\title{
On Farm Assessment of Direct Seeded Rice (DSR) Technology in Humid South-Eastern Plain of Rajasthan, India
}

\author{
R.K. Bairwa*, B.L. Dhaka, B.L. Nagar and K. Mahajani
}

Krishi Vigyan Kendra, Post Box No.04, Bundi- 323001, Rajasthan, India

*Corresponding author

\section{A B S T R A C T}

\begin{tabular}{|l|}
\hline Ke y w o r d s \\
Direct seeded rice, \\
Transplanted, \\
Economics, \\
Resource \\
conservation, \\
Variable cost, \\
Economics \\
\hline Article Info \\
\hline Accepted: \\
20 June 2019 \\
Available Online: \\
10 July 2019
\end{tabular}

On farm trial were conducted during Kharif, 2014 and 2015, to assess the feasibility of Direct Seeded Rice (DSR) options at farmer's field as compared to transplanted rice (TPR) with an objective to reduce cost of cultivation and improve resource use efficiency. Total variable cost saving of 52.06 per cent was observed in direct seeded rice (DSR) as compared to manual puddled transplanted rice. Grain yield under DSR was also recorded significantly higher over the farmers practice but at par with transplanted. On mean basis transplanted rice recorded higher yield $(44.78 \mathrm{q} / \mathrm{ha})$ followed by DSR $(42.57 \mathrm{q} / \mathrm{ha})$ and farmers practice $(39.17 \mathrm{q} / \mathrm{ha})$. DSR technique obviate the cost of nursery raising, puddling and manual transplanting therefore, reduces the cost of cultivation up to 52 percent. Further, it (DSR) gave 12.02 and 27.56 per cent high net return (Rs51968/ha) and benefit cost ratio (2.25) over transplanted paddy, respectively. Therefore, the puddled transplanting of rice could be replaced with DSR to save water and labour and to reduce the cost of rice production to fetches more return to the rice grower farmers

\section{Introduction}

Rice is generally cultivated in Bundi district of Rajasthan by transplanting 25-30 days old nursery seedlings in to the puddled field which requires heavy amount of labour in raising, uprooting of seedlings, puddling and transplanting in the main field leading to a substantial rise in the production cost. Transplanting of paddy seedlings into flooded fields gives the crop a major competitive advantage over weeds as the majority of the weeds are suppressed by the standing water. Rising costs of labour, high water use and energy required for nursery establishment, puddling of fields and transplanting, coupled with labour scarcity during the peak period of activity are the compelling factors to seek an alternative to transplanting of paddy (Sidhu et al., 2014). Direct seeding is an alternative rice cultivation technology that can reduce the labour and energy requirements for crop establishment and the demand for irrigation water. It offers faster and easier planting, 
reduces labour requirement, earlier crop maturity by 7- 10 days, more efficient water use and higher tolerance of water deficit, less methane emission and often higher profit in areas with an assured water supply. In order to check the declining water table, a new technique of direct-seeding is now fast replacing traditional transplanted rice in areas with good drainage and irrigation facilities (Balasubramanian and Hill, 2000). The alternative to puddling and transplanting could be different methods of direct seeding because these do not require heavy amount of labour and crop matures earlier (7-10 days) than transplanted allowing timely planting of succeeding wheat crop (Giri, 1998). Besides these, sowing of wheat is also delayed if conventional land preparation is carried out in wheat which resulted in linear decline in wheat productivity equivalent to 1.0-1.5 percent yield loss / hectare/day (Gathala et al., 2011). Kumar and Ladha (2011) also stated that due to conventional puddling and land preparation in paddy, a yield decline of 8-9 percent has been observed in wheat as compared with non- puddled rice due to disturbance in the soil physical structure. It was convinced that under puddled condition the yield of rice is high but it has its own limitations and ill effects on soil health (Mohanty et al., 2006).

Rice is the major kharif crop of Bundi district of Rajasthan covering 30 thousand hectare area which is harvested upto second week of November which tends towards late sowing of wheat and a substantial decline in wheat yield. Mishra (2003) reported a decrease in seed yield upto $47 \mathrm{~kg} / \mathrm{ha} /$ day and $57 \mathrm{~kg} / \mathrm{ha} /$ day if sowing of wheat is done in the month of December and January, respectively. However, cultivation of direct-seeded rice, weeds are major hurdle for its success (Rao et al., 2007; Rao and Nagamani, 2007) as nearly all kharif season weeds depending upon seed bank in the field infest this crop. Weeds pose major problem in rice production due to the prevalence of congenial atmosphere during kharif season and uncontrolled weeds compete with dry- seeded rice and reduce yield upto $30.17 \%$ (Singh et al., 2005). With direct seeded rice, water saving to the extent of 2030 per cent has been reported by Tabbal et al., (2002). Under these circumstances, direct seeding of paddy appears to be the wise option to save time, energy and labour simultaneously. To address some of the above considerations, an on farm assessment of direct seeded paddy at farmers fields in Humid South-Eastern plain (V) of Rajasthan were carried out

\section{Materials and Methods}

The study was conducted in Bundi district of Rajasthan to assess the feasibility of direct seeded rice. The On Farm Trials (OFT) were conducted at farmer's fields at eight different locations in during kharif, 2014 and 2015. The soil of experiment locations was sandy loam to loam in texture, normal in soil reaction $(\mathrm{pH}$ 7.65-8.06) and electrical conductivity (0.141$0.315-1 \mathrm{dSm})$, low in organic carbon (0.358 $0.421 \%)$, available phosphorus (11.5-24.1 $\mathrm{kg} / \mathrm{ha})$ and available potassium (118-163.7 $\mathrm{kg} / \mathrm{ha}$ ). Seeds of medium duration rice cultivar PS 4 (P 1121) were drilled in rows $22.5 \mathrm{~cm}$ apart with tractor drawn seed cum fertilizer drill in second fortnight of June at $30 \mathrm{~kg}$ seed /ha and the seeds were placed $2-3 \mathrm{~cm}$ depth. After 24-48 hrs of sowing, pre-emergence application of pendimethalin at $1 \mathrm{~kg}$ a.i. per ha was applied and post emergence application of bispyribac sodium at 35 a.i. g per ha was done at 25-30 days after sowing. Nitrogen at $120 \mathrm{~kg}$ per ha was applied in three splits $1 / 3$ at sowing, $1 / 3$ at 30 days after sowing and remaining $1 / 3$ at 55-60 days of crop sowing. Whole phosphorus (60 kg per ha) and potassium (50 kg per ha) was applied at sowing. Iron deficiency was noticed in DSR plots which was counteracted by two sprays of 
$5 \mathrm{~kg}$ ferrous sulphate in 500litres of water per ha at 10 days interval. The direct seeded rice plots were kept moist throughout and $5 \mathrm{~cm}$ irrigation was applied at 10 days interval and irrigation was withheld 10 days before crop harvest. In transplanting (recommended practice) treatment the same variety was used for which sowing in the nursery was done within 10-15 June and thereafter it was transplanted in the field on 10-15 July at the age of 30-35 days at spacing of $20 \times 10 \mathrm{~cm}$. Whereas in transplanting (farmers practices) treatment, crop geometry were not maintain and transplanting the paddy seedling as and where needed (i.e. improper crop geometry). The weed control was done by applying recommended herbicide, pretilachlor at $0.5 \mathrm{~kg}$ a.i. per hectare by mixing in $150 \mathrm{~kg}$ sand after 3 days of transplantation. All other practices during crop growth period were as per the package of practices for kharif crops recommended by Zonal Packages of Practices of Humid South-Eastern plain (V) of Rajasthan. The crop was harvested and threshed manually and yield was computed at $8 \%$ moisture content. Data on crop grain yield were recorded at the time of crop harvest then after economics of the crop was calculate treatment wise to draw valid conclusions. Randomized block design (RBD) was employed to test the significant of the differences in different parameters.

\section{Results and Discussion}

\section{Yield}

The grain yield of paddy was significantly influenced under different sowing methods of paddy (Table 1). During both the years of experimentations, the grain yield of paddy recorded significantly higher under manually transplanted rice over farmers practice treatment but at par with direct seeded rice. Transplanted paddy resulted in 4.83 and 10.75 per cent yield increment over DSR and farmers practice in the year of 2014. While the corresponding increase in 2015 were 5.58 and 16.21per cent, respectively. Further, grain yield under DSR was also recorded significantly higher over the farmers practice but at par with TPS. Per cent increases in grain yield of paddy under DRS over farmers practice were 7.36 and 10.06 during 2014 and 2015, respectively. On mean basis, DSR and TPR brought 8.68 and 13.78 per cent higher grain yield of paddy over farmers practice, respectively. Singh et al., (2006) also observed $10 \%$ yield loss in DSR as compared to manual puddled transplanted rice. Bhusan et al., (2007) and Ladha et al., (2009) also observed that direct seeding on soils often resulted in some loss of rice yield. Similarly, Mangat et al., (2006) also reported significantly higher grain yield (70.8 q ha) of rice with manual transplanting as compared to dry seeding with seed drill and zero till drill. Walia et al., (2009) also recorded significant differences in grain yields of direct seeded rice and puddled transplanted rice at Ludhiana. Sidhu et al., (2014) also observed 3.65 per cent grain yield loss in direct seeded rice over puddle transplanted rice at Ludhiana

\section{Economics}

Cost of cultivation of various treatments was estimated on the basis of approved market rates for inputs by taking into account cost of seed, fertilizer, herbicides, pesticides, hiring charges of human labour and machines for different field operations. Gross returns were calculated on the basis of market rates. The data (table 2) reveal that during both the year of study and on mean basis, total variable cost including nursery raising, puddling, manual transplanting and irrigation/diesel cost were higher under transplanted rice and farmers practice over DSR except ploughing/sowing and weed management cost. On mean basis total variable cost in DSR was 52.06 and 49.52 per cent less over transplanted paddy 
(Rs 19840/ha) and farmers practice (Rs 18840/ha), respectively. Common cost of cultivation like input, harvesting, threshing etc. were similar in all three methods of paddy growing. Further, the significance of DSR in respect to cost of cultivation, net return and $\mathrm{B}$ $\mathrm{C}$ ratio were clearly showed in Table 4. During both the year of experimentation cost of cultivation significantly higher in transplanted rice over DSR and farmers practice. On mean basis cost of cultivation under direct seeded rice was 24.84 and 22.99 per cent low over transplanted rice (Rs 41580/ha) and farmers practice (Rs 40580/ha), respectively. On the other hand, the net returns under DSR were recorded significantly higher over transplanted rice and farmers practice during both the years. On mean basis net return under direct seeded rice was 12.02 and 32.33 per cent higher over transplanted rice (Rs 51968/ha) and farmers practice (Rs 43992/ha), respectively. Similarly, B C ratio was also significantly higher over transplanted rice and farmers practice during both the years. Mean data revealed that DSR method of rice cultivation resulted 27.55 and 39.32 per cent higher B C ratio over transplanted rice (2.25) and farmers practice (2.06), respectively.

Therefore, the significance of DSR show that lower the cost of cultivation and higher the net return and $\mathrm{B} \mathrm{C}$ ration over transplanted rice and farmers practice (Table 3). Gangawar et al., (2008) recorded higher benefit: cost ratio with direct seeded rice as compared to transplanted rice. Kumar (2011) also observed similar findings and found higher $\mathrm{B} \mathrm{C}$ ratio (1.19-1.27) in DSR as compared to (1.08) in manual puddled transplanted rice. These results are in conformity with the finding of Sidhu et al., (2014)

Table.1 Seed yield of paddy under different sowing methods

\begin{tabular}{|c|c|c|c|c|}
\hline \multirow[t]{2}{*}{ Treatment } & \multicolumn{3}{|c|}{ Yield (q/ha) } & \multirow[t]{2}{*}{$\%$ increase over T1 } \\
\hline & 2014 & 2015 & Mean & \\
\hline $\begin{array}{l}\text { T1: Improper crop geometry (farmer } \\
\text { practice) }\end{array}$ & 40.08 & 38.25 & 39.17 & - \\
\hline $\begin{array}{l}\text { T2: Paddy transplanting at } 20 \times 10 \mathrm{~cm} \\
\text { spacing (Recommended) }\end{array}$ & 45.11 & 44.45 & 44.78 & 13.78 \\
\hline $\begin{array}{l}\text { T3: Direct sown paddy with tractor } \\
\text { drawn seed drill }\end{array}$ & 43.03 & 42.10 & 42.57 & 8.68 \\
\hline CD (0.05) & 2.65 & 2.49 & & \\
\hline CV $(\%)$ & 4.10 & 3.95 & & \\
\hline
\end{tabular}

Table.2 Variable cost incurred for paddy cultivation under different sowing methods

\begin{tabular}{|l|l|l|l|l|l|l|l|l|l|l|l|l|}
\hline Treat. & \multicolumn{4}{l}{ Nursery raising } & \multicolumn{4}{l|}{ Puddling } & \multicolumn{3}{l|}{ Transplanting } & \multicolumn{4}{l|}{ Ploughing/sowing } \\
\hline & $\mathbf{2 0 1 4}$ & $\mathbf{2 0 1 5}$ & Mean & $\mathbf{2 0 1 4}$ & $\mathbf{2 0 1 5}$ & Mean & $\mathbf{2 0 1 4}$ & $\mathbf{2 0 1 5}$ & Mean & $\mathbf{2 0 1 4}$ & $\mathbf{2 0 1 5}$ & Mean \\
\hline $\mathbf{T}_{\mathbf{1}}$ & 1800 & 2000 & 1900 & 2800 & 3000 & 2900 & 5500 & 6000 & 5750 & 1440 & 1440 & 1440 \\
\hline $\mathbf{T}_{\mathbf{2}}$ & 1800 & 2000 & 1900 & 2800 & 3000 & 2900 & 6500 & 7000 & 6750 & 1440 & 1440 & 1440 \\
\hline $\mathbf{T}_{\mathbf{3}}$ & - & - & & - & - & & - & - & & 2160 & 2160 & 2160 \\
\hline
\end{tabular}


Table.2 Continue....

\begin{tabular}{|l|l|l|l|l|l|l|l|l|l|l|l|l|}
\hline Treatment & \multicolumn{4}{l}{$\begin{array}{l}\text { Irrigation } \\
\text { / Diesel }\end{array}$} & \multicolumn{4}{l|}{ Weed management } & \multicolumn{3}{l|}{ Total variable cost } & \multicolumn{3}{l|}{$\begin{array}{l}\text { Common cost of } \\
\text { cultivation }\end{array}$} \\
\hline & $\mathbf{2 0 1 4}$ & $\mathbf{2 0 1 5}$ & Mean & $\mathbf{2 0 1 4}$ & $\mathbf{2 0 1 5}$ & Mean & $\mathbf{2 0 1 4}$ & $\mathbf{2 0 1 5}$ & Mean & $\mathbf{2 0 1 4}$ & $\mathbf{2 0 1 5}$ & Mean \\
\hline $\mathbf{T}_{\mathbf{1}}$ & 6000 & 6000 & 6000 & 800 & 900 & 850 & 18340 & 19340 & 18840 & 21320 & 22160 & 21740 \\
\hline $\mathbf{T}_{\mathbf{2}}$ & 6000 & 6000 & 6000 & 800 & 900 & 850 & 19340 & 20340 & 19840 & 21320 & 22160 & 21740 \\
\hline $\mathbf{T}_{\mathbf{3}}$ & 3000 & 3000 & 3000 & 4200 & 4500 & 4350 & 9360 & 9660 & 9510 & 21320 & 22160 & 21740 \\
\hline
\end{tabular}

Table.3 Economics under different sowing methods of paddy

\begin{tabular}{|c|c|c|c|c|c|c|c|c|c|}
\hline \multirow{2}{*}{$\begin{array}{l}\text { Treatmen } \\
\mathbf{t}\end{array}$} & \multicolumn{3}{|c|}{ Cost of cultivation ( $\mathrm{Rs} / \mathrm{ha})$} & \multicolumn{3}{|c|}{ Net return (Rs/ha) } & \multicolumn{3}{|c|}{ B C Ratio } \\
\hline & 2014 & 2015 & Mean & 2014 & 2015 & Mean & 2014 & 2015 & Mean \\
\hline T1 & 39660 & 41500 & 40580 & 41484 & 46500 & 43992 & 2.05 & 2.12 & 2.06 \\
\hline $\mathbf{T} 2$ & 40660 & 42500 & 41580 & 49556 & 54380 & 51968 & 2.22 & 2.28 & 2.25 \\
\hline T3 & 30680 & 31820 & 31250 & 55810 & 60620 & 58215 & 2.82 & 2.91 & 2.87 \\
\hline CD & 1072 & 552 & & 500 & 212 & & 0.058 & 0.024 & \\
\hline CV $(\%)$ & 1.91 & 0.94 & & 0.67 & 0.26 & & 1.63 & 0.66 & \\
\hline
\end{tabular}

Table.4 Comparative economic of transplanted and direct seeded rice (Rs. per hectare)

\begin{tabular}{|c|l|c|c|c|}
\hline S. No. & Details of cost components & Transplanted & DSR & $\begin{array}{l}\text { Saving in DSR } \\
(\mathbf{\%})\end{array}$ \\
\hline $\mathbf{1}$ & Variable cost & \multicolumn{3}{|c|}{} \\
\hline $\mathbf{i}$ & Nursery raising & 1900 & - & 100 \\
\hline ii & Puddling expenses & 2900 & - & 100 \\
\hline iii & Manual transplanting & 6750 & - & 100 \\
\hline iv & Preparatory tillage & 1440 & 2160 & -33 \\
\hline $\mathbf{v}$ & Irrigation & 6000 & 3000 & 50 \\
\hline $\mathbf{v i}$ & Weed management & 850 & 4350 & -411 \\
\hline & Total variable cost & $\mathbf{1 9 8 4 0}$ & $\mathbf{9 5 1 0}$ & $\mathbf{5 2 . 0 6}$ \\
\hline $\mathbf{2}$ & Cost of cultivation (Rs/ha) & 51580 & 31250 & 24.84 \\
\hline $\mathbf{3}$ & Net return (Rs/ha) & 2.25 & 58215 & 12.02 \\
\hline $\mathbf{4}$ & B C Ratio & & 2.87 & 27.56 \\
\hline
\end{tabular}

\section{Comparisons}

It is manifest from data (Table 4) that DSR technology is cost saving in nursery raising (100 per cent), puddling (100 per cent), manual transplanting (100 per cent) and irrigation (50 per cent) over transplanted rice except preparatory tillage (33 per cent) and weed management (411 per cent) involve high cost under DSR. Total variable cost of cultivation under DSR was 54.06 per cent low as compare to transplanted rice (Rs 19840/ha). Further, cost of cultivation in DSR was also 24.84 per cent low over the TPR (Rs 41580/ha). However, net return and cost benefit ratio in DSR were 12.02 and 27.56 per 
cent higher over the TPR (Rs 51968/ha and 2.25), respectively. These data (Table 4) reflect the significance of DSR over TPR at farmer field in view of economic point. The results also show that cost saving in the DSR is more than that of increase in yield under transplanted that leads towards better economics of DSR technology. These results are in conformity to the work of Nai-Kin and Romli, (2002), according to which direct seeding enabled farmers in Muda area of Malaysia to save $29 \%$ of the total cost of transplanted crop.

Based on study findings, it is concluded that DSR technology is better as compared to conventionally transplanted method of rice production if practiced properly as net economic returns and Benefit Cost Ratio were better under DSR technology than transplanting technique. In spite of better economics, weeds management is still a major obstacle in the way of adoption of DSR technology that leads to lower yield in DSR method as compared to transplanting technique. DSR has viable alternative to overcome the problem of labour and water shortage.

Despite controversies, if properly managed, comparable yield may be obtained from DSR compared with TPR. If not managed efficiently, weeds may cause partial to complete failure of DSR crops. In DSR culture, water use efficiency (WUE) and productivity may increase if appropriate leveling of lands is done. Early crop vigour, short stature and short duration may also improve WUE. Poor stand establishment is another hindrance in the wide-scale adoption of DSR.

Effective seed priming techniques has helped to resolve this issue. It would be good if the capabilities of farmers to manage natural resources in sustainable manner are enhanced and rice productivity is increased through developing knowledge and technology of direct seeding by way of research and extension activities.

\section{References}

Balasubramanian, V. and Hill, J. 2000. Direct wet seeding of rice in Asia: Emerging issues and st strategic research needs for the 21 century. Annual Workshop of the Directorate of Rice Res., Hyderabad, Andhra Pradesh.

Bhusan, L., Ladha, J.K., Gupta, R.K., Singh, S. Tirole-Padre, A., Sehrawat, Y.S., Gathala, M. and Pathak, H. (2007). Saving of water and labour in rice-wheat system with no tillage and direct seeding technologies. Agronomy Journal 99: 1288-1296.

Ganawar, K.S., Tomar. O.K. and Pandey D.K. 2008. Productivity and economics of transplanted and direct-seeded rice (Oryza sativa)-based cropping systems in IndoGangetic plains. Indian Journal of Agriculture Sciences 78: 655-58.

Gathala, M.K., Ladha, J.K., Kumar, V., Saharawat, Y.S., Kumar, V., Sharma, P.K., Sharma, S. and Pathak, H. 2011. Tillage and crop establishment affects sustainability of South Asian rice-wheat system. Agronomy Journal 103:961-971.

Gill, M.S. 2008. Productivity of direct-seeded rice (Oryza sativa) under varying seed rates, weed control and irrigation levels. Indian Journal of Agriculture Sciences 78: 32-36.

Giri, G.S. 1998. Effect of rice and wheat establishment technique on wheat grain yield. In. Proc. Rice- Wheat Res. Project Workshop, pp. 65-68.

Kumar, Rakesh. (2011). Unpublished M. Tech. Thesis on "Comparative performance evaluation of mechanical transplanting and direct seeding of rice under puddled and unpuddled condition". Deptt. of Farm Machinery and Power Engineering, CCS HAU, Hisar, Haryana, India.

Kumar, V. and Ladha, J.K. 2011. Direct seeding of rice: recent developments and future research needs. Advances of Agronomy 111:297-313 
Ladha, J.K., Kumar, V., Alam, M., Sharma, S., Gathala, M., Chandna, P., Sehrawat, Y.S. and Balasubraminian, V. (2009). Integrated crop and resource management technologies for enhancing productivity, profitability and sustainability of the ricewheat system in South Asia. In: Ladha, J.K. (Ed.), Integrated crop and resource management in rice-wheat system of South Asia. IRRI, Los Banos, Philippines, pp. 69108.

Mangat, R., Hari, O., Dhiman, S.D. and Nandal D.P. 2009. Productivity and economics of rice-wheat cropping system as affected by establishment methods and tillage practices. Indian Journal of Agronomy 51: 77-80.

Mishra, R.D. 2003. Wheat research at Pantnagar, Research bulletin No. 132, G.B. Pant University of Agriculture and Technology, Pantnagar, India pp 26-27.

Mohanty, M., Painuli, D.K., Mishra, A.K., Bandyopadhyaya, K.K. and Ghosh, P.K. 2006. Estimating impact of puddling, tillage and residue management on wheat seedling emergence and growth in a rice-wheat system using nonlinear regression models. Soil and Tillage Research 87(1):119- 130.

Nai-Kin H. and Romli Z, 2002. Impact of direct seeding on rice cultivation: lessons from the Muda area of Malaysia, pp.87-98. In Proceedings of the International Workshop on Direct Seeding in Asian Rice Systems: Strategic Research Issues and Opportunities, 25-28 January 2000, Bangkok, Thailand. Los Baños (Philippines): International Rice Research Institute.

Rao, A.N. and Nagamani, A. 2007. Available technologies and future research challenges for managing weeds in dry-seeded rice in
India. In: st th Proc. 21 Asian Pacific Weed Sci. Soc. Conf. 2 to 6 October 2007, Colombo, Sri Lanka.

Rao, A.N., Mortimer, A.M., Johnson, D.E., Sivaprasad, B. and Ladha, J.K. 2007. Weed management in direct-seeded rice. Advances of Agronomy 93: 155-257.

Sidhu, A.S, Kooner, R. and Verma, A. 2014. Onfarm assessment of direct-seeded rice production system under central Punjab conditions. Journal of Crop and Weed 10(1):56-60

Sidhu, A.S., Kooner, R. and Verma, A. 2014. Onfarm assessment of direct-seeded rice production system under central Punjab conditions. Journal of Crop and Weed 10(1): 56-60

Singh, K.K., Lohan, S.K., Jat, A.S. and Rani, Tulsa. (2006). New technologies of planting rice for higher production. Research on Crops. 7: 369-371.

Singh, V.P., Singh, G., Singh, R.K., Singh, S.P., Kumar, A., Dhyani, V.C., Kumar, M. and Sharma, G. 2005. Effect of Herbicides alone and in combination on direct seeded rice Indian Journal of Weed Science. 37: 197-01

Tabbal, D.F., Bourman, B.A.M., Bhuiyan, S.I., Sibayan, E.B. and Sattar, M.A. 2002. Onfarm strategies for reducing water input in irrigated rice: Case Studies in the Phillipines. Agril. Water Management, 56: 93-112.

Walia, U.S., Bhullar, M.S., Walia, S.S., Sidhu, A.S. and Nayyar, Shelly. 2009. Scope of direct seeded rice in Punjab. In. Proc. Nat. Workshop on Scope and Problems Direct Seeded Rice. PAU, Ludhiana. pp. 6-23.

\section{How to cite this article:}

Bairwa, R.K., B.L. Dhaka, B.L. Nagar and Mahajani, K. 2019. On Farm Assessment of Direct Seeded Rice (DSR) Technology in Humid South-Eastern Plain of Rajasthan, India. Int.J.Curr.Microbiol.App.Sci. 8(07): 2492-2498. doi: https://doi.org/10.20546/ijcmas.2019.807.307 